\title{
Janka Kaščáková
}

\section{Speaking Silence \\ in "The Daughters of the Late Colonel"}

\begin{abstract}
Detachment from meaningful movement in time; the gradual development of history disrupted by absurdity and the cruelty of the First World War; the wasteland of European civilization and the reduction of individuals into ghastly numbers; human existence no longer firmly attached with regard to meaning: all this, in Modernist texts, translates into both scattered bits and conflicted yet meaningful juxtapositions. To use T.S. Eliot's famous line, literature becomes a "heap of broken images" and all authors wish to express this disruption and deal with it in their own particular way. One of the direct representations of the inability of writers to cope with contemporary reality is the fragmentation of the text, often accompanied by the frequent use of ellipses. This is especially noticeable in the works of the New Zealand Modernist Katherine Mansfield; her short stories build on what is said as much as on what is left unsaid; they make use of empty spaces bearing meaning, speaking silence- all this requires an active reader, drawn into the creation of the story. This paper discusses Katherine Mansfield's short story "The Daughters of the Late Colonel," with an emphasis on the unexpressed, or implied, the use of ellipses and omissions; it analyzes their interactions with the content of the story; and concludes that what has been omitted is as important as what has been included.
\end{abstract}

The fragmentation of the Modernist text is usually attributed to a consequence of two phenomena: the first is the reaction of writers to the "over-furnished"1 fiction of the 19th century which focused on the "objective," tangible external world of their contemporary society and delighted in describing it in minute detail; the second is writers' attempts to cope with the impact of the Great War, which broke the seeming logic and order of life into shattered pieces, T. S. Eliot's "heap of broken images." The broken text leaves great portions of empty space, mostly figuratively, but sometimes literally, which have to be accounted for, contemplated, and filled in. Ellipses, omissions and things left unsaid, although far from being an invention of Modern-

1. Willa Cather, Not Under Forty [online], Project Gutenberg of Australia eBook, 21 May $2008<$ http://gutenberg.net.au/ebookso5/0500441.txt>.

The AnaChronisT 15 (Winter 2010): 93-103 ISSN 1219-2589 
ists, become more frequent than at any time before; indeed, they became the cornerstone of Modernist aesthetics.

Among those who made creative use of omissions and empty space was the New Zealand short story writer Katherine Mansfield. By its very nature the genre of the short story requires that many things be omitted, yet Mansfield went much further than most short story writers. As she once claimed "[t]he truth is one can get only so much into a story; there is always a sacrifice. One has to leave out what one knows and longs to use. ... It's always a kind of race, to get in as much as one can before it disappears." And although at first it appears to be a disadvantage of the genre, she managed to turn this "leaving out" into one of the strongest points of her writing. Through her ingenious use and selection of detail, the structuring of her texts and her use of juxtapositions, she managed to communicate much more than was usually expressed in the restricted space of the short story. Arguably the best example of this is her masterpiece, "The Daughters of the Late Colonel." Thus in this paper I will elaborate on the use of omissions and ellipses and analyze their interactions with the content of the story, highlighting Mansfield's manifold uses of silence, empty space, or "nothingness" which, I argue, contribute to the density and richness of this story.

Katherine Mansfield commented on the necessity of new forms of writing for the post-war era, especially in connection with Virginia Woolf's Night and Day, which she reviewed for The Athenaeum in 1919. Her main objection, expressed in this much quoted and commented on review, was that the novel, which she likens to a ship at sea, sails back to the port aloof, with an "air of quiet perfection," and lacks "any sign that she has made a perilous voyage."3 Mansfield quite clearly declared that after the war no ship could be untouched, that is, no novel should be written in the pre-war, realistic tradition. She further clarified her distinct dislike of this kind of writing in a letter to J. M. Murry, where she insisted on the necessity of change in the writing of literature:

I don't want (G. forbid) mobilization and the violation of Belgium, but the novel can't just leave the war out. There must have been a change of heart. ... I feel in the profoundest sense that nothing can ever be the same - that, as artists, we are traitors if we feel otherwise: we have to take it into account and find new expressions, new moulds for our thoughts and feelings. ${ }^{4}$

2. Margaret Scott, ed., The Katherine Mansfield Notebooks (Minneapolis: University of Minnesota Press, 2002), p. 318.

3. Katherine Mansfield, Novels and Novelists (New York: Knopf, 1930), p. 108.

4. Vincent O'Sullivan and Margaret Scott, eds., The Collected Letters of Katherine Mansfield, Volume 3: 1919-1920 (Oxford: Clarendon Press, 1993), p. 82. 
Thus the war and its brutality are not to appear directly, as themes; the cataclysm of destruction, the millions of young lives lost in the anonymous military machinery, as well as the abuse of scientific progress all must be reflected in the way literature is written. Old genres must be reassessed and reshaped; and new ones should arise to better accomplish the expression of the new reality.

Yet it would be too simplistic to claim that Mansfield's distinctly modern way of writing is a direct consequence of simply, in her case, her personal experience with war. Long before the conflict broke out, reading Symons' Studies in Prose and Verse she entered into her notebook:

The partisans of analysis describe minutely the state of the soul; the secret motive of every action itself. The partisans of objectivity - give us the result of this evolution sans describing the secret processes. They describe the state of the soul through the slightest gesture - i.e. realize flesh covered bones - which is the artist's method for me - in as much as art seems to me pure vision - I am indeed a partisan of objectivity. 5

This "slightest gesture," which must be carefully selected in order to produce the wished-for effect, is closely related to Joyce's epiphany, or Woolf's "moment of being." Mansfield calls it a "glimpse," and Gillian Body aptly identifies it as the "glimpse of a specific character at a specific moment, as if through an open doorway." 6 Thus the success of the story depends on the careful selection of this moment and the way it is depicted, resulting in the amount and quality of what the readers will be able to find there, and how much they will be able to understand.

Omission, repression and silence are at the core of "The Daughters of the Late Colonel," first published in 1920. This story of two sisters seemingly covers only the few days directly following the death of their father. Yet, as the story unfolds, it becomes clear that what the two sisters say, do and remember, or rather, what they fail to say, do or remember, presents their past, although this past must be assembled, reconfigured as it were, by the reader, who is also, thereby, invited to guess at their future. Thus the reader is called upon to construct a much wider stretch of time than that directly represented in the story itself. This result is achieved not only through narrative gaps, but through the structure, as well.

On the level of structure, this story is divided into 12 separate and numbered parts each covering a small portion of the daughters' present, as well as some

5. Alexander Turnbull Library Notebook 2 - annotation of Symons' Studies in Prose and Verse 1904; quoted in Clare Hanson, ed., The Critical Writings of Katherine Mansfield (New York: St.Martin's Press, 1987), p. 58.

6. Gillian Body, Katherine Mansfield: The Woman and the Writer (Victoria, Australia: Penguin, 1988), p. 169. 
selected flashbacks into a more or less distant past. The individual sections are not ordered chronologically and might, at first sight, appear to have been arranged randomly. Yet this impression lasts only until the reader realizes that the arrangement is not external but internal, functioning according to the 'logic' and ordering of the daughters' minds. Thus the story reaches an almost absurdist mode, in which the reader must enter into the story and accept its conditions rather than approach it from the outside, with traditional expectations and assumptions. To achieve this, KM employs another favourite among her narrative techniques: free indirect discourse. Thus the world is seen through the eyes of the sisters, through their thoughts and consciousnesses, which interact and mingle to the point that it is sometimes difficult to distinguish whose ideas are presented, or by whom.

Constantia and Josephine, or Con and Jug as they call each other, are middle-aged, unmarried sisters who lost their mother in childhood and have lived with their authoritative and bullying father ever since. The story opens at the time of his death, usually a traditional time for a family to reminisce about and evaluate the past and discuss the future. Yet in this story neither of the sisters is able to do either. As a result the reader, expecting a traditional story, with some turning point, climax, change, or solution, becomes frustrated because there is none. Further, there can be none because of the empty and dependent existence that the two women had been forced to endure for such a very long time. However unpleasant their lives may have been, Con and Jug are lost without their father: their life experiences have been extremely limited, their lives quite sheltered, and all their actions censored by him. Such "protection" leaves them unable to act independently after his death and even results in tragicomic situations, such as the one during his funeral:

Josephine had had a moment of absolute terror at the cemetery, while the coffin was lowered, to think that she and Constantia had done this thing without asking his permission. What would father say when he found out? For he was bound to find out sooner or later. He always did. "Buried. You two girls had me buried!" She heard his stick thumping. Oh, what would they say? What possible excuse could they make? It sounded such an appallingly heartless thing to do. Such a wicked advantage to take of a person because he happened to be helpless at the moment. The other people seemed to treat it all as a matter of course. They were strangers; they couldn't be expected to understand that father was the very last person for such a thing to happen to. No, the entire blame for it all would fall on her and Constantia. And the expense, she thought, step- 
ping into the tight-buttoned cab. When she had to show him the bills. What would he say then?

She heard him absolutely roaring. "And do you expect me to pay for this gimcrack excursion of yours?"

$\left(235^{-236}\right)^{7}$

Nowhere in the text is it expressed that the treatment of their father was unfair or cruel, yet such reactions of the sisters express the extent of his abuse quite eloquently. "What would they say" to their father is in fact a leitmotif of their lives, implying that no answer can possibly be correct and no expense satisfyingly low for him. The old manipulator has instilled such a sense of guilt into them that they have a fit of panic when they realize they had buried him without his permission. What is more, they do not shake off this absurd idea but feel that "father will never forgive [them] for this - never!" (236)

Another example that indicates the way the sisters' were drilled and had to be obedient to the point of absurdity presents itself when, after the death of their father, Con and Jug suddenly hear an organ-grinder in the street. Obviously taught to get rid of him so that he not disturb their father, and to do so as quickly as possible, they react instinctively and immediately:

But at that moment in the street below a barrel-organ struck up. Josephine and Constantia sprang to their feet together.

"Run, Con," said Josephine. "Run quickly. There's sixpence on the -"

Then they remembered. It didn't matter. They would never have to stop the organ-grinder again. Never again would she and Constantia be told to make that monkey take his noise somewhere else. Never would sound that loud, strange bellow when father thought they were not hurrying enough. The organ-grinder might play there all day and the stick would not thump. It never will thump again,

It never will thump again, played the barrel-organ.

The abusive behaviour of Colonel Pinner is again obvious without being explicitly expressed. He terrorized his daughters by abusive words (make that monkey take this noise somewhere else), by the thumping of the stick and shouting at them. And since the funeral episode shows that he was also watching over the expenses, it is hardly believable that he would authorize them to pay the "monkey" the sixpence they had had prepared for him. It implies they preferred to save from the little money they had and pay the organ-grinder just to be in peace.

7. All parenthesised references are to this edition, Katherine Mansfield, Selected Stories, ed. Angela Smith (Oxford: Oxford University Press, 2002). 
But Colonel Pinner is not the only one the sisters are afraid of. They are even intimidated by their own servant, Kate, who, feeling their weakness and her power over them, immediately takes advantage of the situation:

And proud young Kate, the enchanted princess, came in to see what the old tabbies wanted now. She snatched away their plates of mock something or other and slapped down a white, terrified blancmange.

"Jam, please, Kate," said Josephine kindly.

Kate knelt and burst open the sideboard, lifted the lid of the jam-pot, saw it was empty, put it on the table, and stalked off.

This quotation is a nice example of Mansfield's ability to present the reader with much information in a very limited space, using what Antony Alpers referred to as the "floating narrator," smoothly passing between different consciousnesses of characters and presenting the readers with a more complex and objective view of the situation. In the first two sentences the reader is presented with Kate's attitude towards her employers: she calls them old tabbies, for whom she has cooked a "mock something," which she snatches away before slapping down their meal. The sisters' fear of Kate is mirrored by that of the "terrified blancmange." But wonderfully most ambiguous here is the characterization: "the enchanted princess." One possibility is Mansfield's own ironic comment - through the narrator - about the servant. It could also represent the sister's view of this - for them surely - enigmatic person who, although a servant, is bold and arrogant, clearly terrifying for them, having power over them. But it could also depict Kate's own vision of herself: as a young girl, having a boring, menial but demanding job, she, as many young women of her age and situation, may indeed imagine that the life she is leading is just temporary and, as in the case of princesses from fairy-tales, the enchantment will one day lift and she will be able to leave this existence and lead a full life. Yet all this can be only guessed by the reader; the writer remains silent, leaving the meaning to be extracted from the text.

One of the techniques Mansfield employs to reveal the total helplessness and incapacitation of the sisters is incoherent and incomplete direct or indirect discourse. In moments of insecurity, distraction, when the sisters are confused or agitated, their thoughts are represented by broken syntax, dashes, repetitions and ellipses. A simple question from their servant Kate about the way she should prepare the fish elicits this reaction:

"I think it might be nice to have it fried," said Constantia. "On the other hand, of course boiled fish is very nice. I think I prefer both equally well. . .

Unless you. .. In that case -" 
Taking into consideration the previous quotation concerning Kate, the reader might well wonder whether it is this kind of attitude that made Kate behave as she did towards them, or the other way round: that is, whether the sisters, intimidated by her rudeness (as they are by their father's), are trying to avoid trouble by this ridiculous way of giving Kate more decision-making power than she ought to have.

Their unimportance and marginal place in society is expressed by the polite yet reluctant visit of their nephew - who comes but who tries to spend as little time with them and their father as possible. His ellipses and dashes represent his unease in dealing with his aunts' world, a world so very different from his own; his belief that time is unimportant for them; that they cannot understand the matters of the "big world" and, as an attentive reader might suspect, that he is not exactly telling them the truth:

"It is, all the same," said Cyril. "I had to meet a man at Victoria, and he kept me hanging about till... there was only time to get lunch and to come on here. And he gave me - phew" - Cyril put his hand to his forehead - "a terrific blow-out," he said.

Although short, his visit is "one of [the sisters'] rare treats" (241), and in spite of its shortness and awkwardness, they remember it with pleasure.

The ellipses often represent the unrealized opportunities or desires of the sisters, which is why it seems difficult if not impossible for both Constantia and Josephine to articulate them. The sisters have very little experience with the outside world and that perhaps is why their dreams have a much less distinct shape than the dreams of other people, who have come across the things they desire in their real lives - if not personally, at least through the stories/experiences of people they have met:

But Constantia's long, pale face lengthened and set, and she gazed away away - far over the desert, to where that line of camels unwound like a thread of wool. . .

This little escape into the world of fantasy occurs during a meal with their late father's nurse; and while Josephine is scandalized by the nurse's eating habits and affected speech, Constantia wanders off into the desert for a little while.

The ellipses also indicate that a great part of the sisters' lives is not worth talking about. These segments brought neither adventure nor simple satisfaction; and it is quite futile to recall them. After she realizes that there is no need to chase away the organ grinder anymore, for example, the sun falling on the old picture of their mother reminds Josephine of their tedious childhood: 
Josephine remembered standing on a chair and pointing out that feather boa to Constantia and telling her that it was a snake that had killed their mother in Ceylon... Would everything have been different if mother hadn't died? She didn't see why. Aunt Florence had lived with them until they had left school, and they had moved three times and had their yearly holiday and. . . and there'd been changes of servants, of course.

The first ellipsis is rather mysterious. It can simply indicate Josephine's moment of distraction or suggest that it is all she knows or remembers about their mother. Yet it may also express doubt about the truthfulness of this story she once accepted without question. By now knowing the nasty character of Colonel Pinner, the reader's curiosity and doubts can indeed be awakened or heightened by such an ellipsis.

The second ellipsis seems to actually talk about the triviality of the sisters' existence - the long years filled with even less interesting and important things than the change of servants. Josephine's reflections bring her to the recollection of their one experience remotely suggesting romance, and even that is trivial and tragicomic:

One read of people having adventures, being followed, and so on. But nobody had ever followed Constantia and her. Oh yes, there had been one year at Eastbourne a mysterious man at their boarding-house who had put a note on the jug of hot water outside their bedroom door! But by the time Connie had found it the steam had made the writing too faint to read; they couldn't even make out to which of them it was addressed. And he had left next day. And that was all. The rest had been looking after father, and at the same time keeping out of father's way.

The appearance and departure of the usual "mysterious man" of teenage-girl literature and fantasies results in an anticlimax, a gap of silence never to be explained. The fact that it is this incident - and that was all - which the sisters recall after so many years is another indication of the flatness of their life.

It is thus no accident that Mansfield chose to present the sisters in the only moment of their lives that can be considered a moment of crisis: the death of their father. No matter how incredible it might seem, this is, as the first sentence of the story implies, probably the most important and most exciting time of their life. It is actually the first time they are able to emerge from their silence and submission, but also to act and decide things for themselves, without their father. This could and should be the final break, the moment when they will be set free.

Yet breaking free is almost impossible for them because they have never been trusted with any responsibility, never been allowed to decide for themselves. In- 
stead of relief and expansion the sisters experience even greater and more cumulative anxiety and fear: during the usual pre-funeral arrangements they are traumatized when offered "a little communion" by their priest, or nearly incapacitated when they cannot decide to whom and how to give out some of their father's possessions. The simple act of entering their father's room and sorting out his things is not an emotionally distressing task but a deeply terrifying experience:

It was dark in the hall. It had been a rule for years never to disturb father in the morning, whatever happened. And now they were going to open the door without knocking even... Constantia's eyes were enormous at the idea; Josephine felt weak in the knees.

Then the door was shut behind them, but - but they weren't in father's room at all. They might have suddenly walked through the wall by mistake into a different flat altogether. Was the door just behind them? They were too frightened to look. Josephine knew that if it was it was holding itself tight shut; Constantia felt that, like the doors in dreams, it hadn't any handle at all.

(237)

The nightmarish door without a handle aptly indicates their powerlessness and their reliance on their father. Their situation now, rather than liberating, is hopeless. Their father, ruthless in his life, continues his hold on them even in death. Further, he robs them even of a decent memory of his death:

Then, as they were standing there, wondering what to do, he had suddenly opened one eye. Oh, what a difference it would have made, what a difference to their memory of him, how much easier to tell people about it, if he had only opened both! But no - one eye only. It glared at them a moment and then... went out.

The ellipses in this extract create a sense of suspension; the reader can almost feel the tension as the sisters hold their breath in this timeless moment. But it also indicates their expectations of death, and their disappointment, anger even, over his way of dying. They will lose the opportunity to talk about his last moments to people in a pleasant, perhaps romantic way. It is paradoxical that they regret that he did not die in a way that would have made it easier for them to remember, and to present to the outside world. But they also fail to recognize that he did not live that way either. He died as he lived: his eye "glared at them a moment and then ... went out" (my emphasis). Only after the suspense of the ellipsis do we learn that it did not close; it went out: presumably, remaining open. Apart from it being quite an unusual thing to happen, at least this is what the sisters seem to feel; it is also an ominous portent of what their future life will be. The eye will remain open forever, 
glaring at whatever they will be doing, watching them and thus never leaving them in peace.

I mentioned earlier that the narrative structure contributed to the sense of absence, though at first the arrangement of the sections seemed arbitrary. But it becomes clear that they represent moments of importance, pleasure, distress, or, as it happens, are simply etched into the sisters' consciousness more distinctively. When these clear moments pass, the sisters again dissolve into greyness, stereotype, and yet mystery.

Constantia lifted her big, cold hands as if to catch them, and then her hands fell again. She walked over to the mantelpiece to her favourite Buddha. And the stone and gilt image, whose smile always gave her such a queer feeling, almost a pain and yet a pleasant pain, seemed to-day to be more than smiling. He knew something; he had a secret. "I know something that you don't know," said her Buddha. Oh, what was it, what could it be? And yet she had always felt there was. . . something.

(247)

Don Kleine very aptly called "The Daughters" "the orphans of time" 8 - which they really are; time left them at the same moment as their mother, stuck in the groove of the gramophone record; their life is a never-ending repetition. They know there are other ways of living, but by now they have neither the courage nor the ability to try one. It is a paradox that, on the one hand, time was absent, on the other, only too present: developmentally they are like children but physically adult, and so doubly sensitive to the forces of the outside world. Unlike children, they have no hope of ever growing up and becoming independent. The tormentor is dead; so is any purpose of life. Theoretically his death should have set them free, but practically it made them even more confused. They are no more alive than their father.

After the publication of "The Daughters of the Late Colonel" Mansfield is recorded to have said to her friend Dorothy Brett that "even dear old Hardy told [her] to write more about those sisters. As if there was any more to say." 9 And truly, one can hardly find a better meeting between the old world and the modern one. "Dear old Hardy" wishing to be told every detail about the two sisters, and hear more stories about their life; and young Mansfield who, although with respect, cannot understand what more she should say. Every new sentence would be just a useless repetition of what had already been said. And everything had already been "said."

8. Don W. Kleine, "Mansfield and the Orphans of Time," Modern Fiction Studies 24:3, (Autumn 1978) 423-438.

9. Anthony Alpers, The Life of Katherine Mansfield (London: Jonathan Cape, 1980), p. 330. 
Katherine Mansfield managed to express so much in so restricted a space as a short story by making use of such structural innovations - in the case of this story as the "random" assortment of incidents in the life of the daughters, as well as ellipses, dashes and other punctuation marks which gradually lose both their grammatical function as well as their character as mere accessories, and become dynamic parts of the text. Her deliberate and creative use of punctuation in occasional combination with an original structural division of the text gives her stories a new dimension, richness and density, creating a synergy whereby the whole is much greater than the sum of its parts. As Willa Cather commented on Mansfield's work:

She communicates vastly more than she actually writes. One goes back and runs through the pages to find the text which made one know certain things about Linda or Burnell or Beryl, and the text is not there - but something was there, all the same - is there, though no typesetter will ever set it. It is this overtone, which is too fine for the printing press and comes through without it, that makes one know that this writer had something of the gift which is one of the rarest things in writing, and quite the most precious. ${ }^{10}$

This "something", or, more precisely, "nothing", the "empty space" which Cather feels, forms an integral part of Mansfield's writing, and confirms that the "new mould" she chose to employ did work the way she wanted it to. But it is a mould which need not be completely filled. For Mansfield's writing suggests that she, too, as did many Modernists, believed that sometimes the most important part of the work of art can be what the artist has left out ${ }^{11}$ both in terms of what she is talking about and how she is talking about it.

10. Cather.

11. Stéphane Mallarmé, "La Musique et les letters," Oeuvres Complètes (Paris, 1945), 635657; paraphrased by Stephen Kern, The Culture of Time and Space (Cambridge, Massachusetts: Harvard University Press, 2003), p. 173. 